\title{
ILMENITE-BEARING PERIDOTITES AND MEGACRYSTS FROM DALNAYA KIMBERLITE PIPE, YAKUTIA.
}

Rodionov $^{(1)}$, A.S.; Sobolev $^{(1)}$, N.V.; Pokhilenko ${ }^{(1)}$, N.P.; Suddaby ${ }^{(2)}$, P. and Amshinsky ${ }^{(1)}$, A.N.

(1) Institute of Geology and Geophysics, Novosibirstk, URSS;

(2) Imperial College of Science and Technology, London. UK.

Dalnaya kimberlite pipe is outstanding among Yakutian kimberlites in terms of abundance of ilmenite peridotite xenoliths and megacrysts.

Our collection consists of about 200 megacrysts of Ilm, Cpx, Gar, Opx, and Ol and their intergrowths and inclusions in different combinations. Ilmenite-pyrope peridotite compose about about $10 \%$ of all ultramafic xenoliths population and exceed 100 samples.

\section{Ilmenite-pyrope lherzolite (IL)}

All samples are altered to different extent. Therefore, in many cases we could not analyse Opx, but its presence in most samples is proved by typical bastitic pseudomorphs and (or) by Gar composition.

The majority of ilmenite peridotites xenoliths belong to a lherzolite paragenesis type $(\mathrm{Ol}+\mathrm{Cpx}+\mathrm{Opx}+\mathrm{Gar}+\mathrm{Ilm}+\mathrm{Phl})$.

Several points should be underlined summarising this group petrography.

1) some xenoliths have a sheared structure, many - a mosaic one and most part - transitional from mosaic to granular structure. Just small part of these xenoliths reveals typical granular structure.

2) Gar grains are zoned in many samples, what one can see either under binocular or from profile analysis (Rodionov, 1988). For sample D-60/79 difference in concetrations reaches for $\mathrm{Cr}_{2} \mathrm{O}_{3}$ (core-rim, wt\%): 6.77-1.05; CaO: 6.27-4.78; $\mathrm{Al}_{2} \mathrm{O}_{3}$ : 16.8-21.4; $\mathrm{MgO}$ : 17.9-19.5; for FeO, $\mathrm{MnO}$ and $\mathrm{TiO}_{2}$ no significant variations were fixed. In some samples with zoned garnets (normally about $6-10 \mathrm{~mm}$ in size) small grains $(0.2-1 \mathrm{~mm}$ ) of second generation Gar are present. Composition of GarII grains corresponds to outer zones of GarI. Core of GarI normally is free of ilmenite inclusions, that appear in the rim. Ilmenite inclusions from the inner part of the rim sometimes differ in composition from grains in matrix (in D-60/79: $\mathrm{TiO}_{2}$ - 54.3-52.7, $\mathrm{Al}_{2} \mathrm{O}_{3}$ - 1.55-0.73, $\mathrm{MgO}$ - 15.9-12.5 wt\%). For Cpx, Opx or Ol no signs of zoning were fixed.

3) Practically all samples contain "pools" of greenish-black highly altered aggregates, that develop along grain boundaries or form rounded "bays" along fractures in all minerals. Serpophite, mica, ore minerals and ochre material composed these pools. We considere these aggregates as products of alteration of partial (residual?) melt.

P-T parameters of equilibria are lower than ones for South Africa analogs (900$1120^{0} \mathrm{C}$ at $\left.30-35 \mathrm{~kb}\right)$. 


\section{Megacryst suite (M)}

Abundance of megacrysts permits to compare Dalnaya pipe with Monastery pipe (South Africa). General features of their appearance are simmilar to megacryst suites described in other localities. So we will concentrate here on peculiarities of Dalnaya pipe megacrysts.

1) They are a bit less in average size than African ones. Accepting after P.H.Nixon and F.R.Boyd (1973) the lowest dimension of $1 \mathrm{~cm}$ it is $2.5 \mathrm{~cm}$ with maximum (cm): Gar - 4.0, Ilm - 5.9, Cpx - 6, Opx - 3, Ilm-Cpx intergrowths - 9.5.

No one typical graphic intergrowth of Ilm and silicate was found. On the other hand several megacrysts of high chromium type were recorded similar to Sloan pipe (USA, Eggler, MacCallum, 1976).

The majority of Ilm megacrysts are recrystallized either totally or more common partly. Gar megacrysts often bear traces of partial melting.

Compositions of megacrysts do not reveal "crystallization" trends like South African suites. There is only general tendency appearing in enrichment of all minerals in $\mathrm{Fe}, \mathrm{Al}$ and $\mathrm{Ca}$ contents in association with Ilm. Like and for (IL) equilibria parameters are lower in comparison to South Africa $\left(900-1050^{\circ} \mathrm{C}\right.$ and $\left.\mathrm{P}<30 \mathrm{~kb}\right)$. For several discrete Cpx nodules T reaches $1200-1250^{\circ} \mathrm{C}$.

\section{Ilmenite-pyrope wehrlites (IW)}

The most interesting Ilm-bearing assemblage is a first time established in Dalnaya paragenetically proved xenoliths and megacrysts of ilmenite-pyrope wehrlite (Rodionov et. al., 1977; Rodionov, Pokhilenko, Amshinsky, 1989).

All reported earlier xenoliths of this type were either not accompanied with mineral analysis or Gar analysis corresponded to two-pyroxene types of paragenesis and therefore such samples were called according to composing minerals proportions.

Xenoliths have unusual structure and are composed of big (up to $2.5 \mathrm{~cm}$ ) crystals of $\mathrm{Gar}+\mathrm{Cpx}+\mathrm{Ilm}+\mathrm{Ol}+\mathrm{Phl}$ (the two last fases can be not presented). Ol is practically totally serpentinized. There is a small grained $(0.2 \mathrm{~mm})$ aggregate of the same minerals $+\mathrm{Amph}+$ Spnl in interstices and along fractures in the big crystals. We consider this material as product of quenching of partial melt what is confirmed by very strong zoning of small euhedral spinels in sample D-100/81 and euhedral form of Cpx.

Megacrysts of the same paragenesis look very much alike "normal" lherzolitic type and can be distinguished only on the basis of their chemistry (Gar first of all).

As we have only four xenoliths and their both structure and composition of big crystals strongly corresponds to megacrysts of the same type their compositions were combined in following discussion.

Temperature range of equilibria is estimated as $800-880^{\circ} \mathrm{C}$ (assuming pressure $25 \mathrm{~kb}$ ).

\section{Discussion and summary}

It is reasonable to compare compositional variations of minerals from all considered groups as they are presented in the same kimberlite body. Another point is that in xenoliths 
of Ilm lherzolites occasionally mineral grains reaching $1 \mathrm{~cm}$ occur. And disintegration of such xenoliths can be one of the sources of megacrysts in kimberlite matrix.

Comparison of all corresponding minerals between groups show:

1. Inside no one group crystallization trend can be reconstructed on the basis of major elements chemistry.

2. As could be suggested range of composition of discrete nodules overlaps variations for each individual group.

3. If to compare average composition for each group (for association with $\mathrm{Ilm}$ ) a certain tendency appears quite evident. In the range IL-M-IW of all minerals regularly increases while $\mathrm{Cr}$-contents is decreasing; for $\mathrm{Cpx}$ ratio $\mathrm{Ca} / \mathrm{Ca}+\mathrm{Mg}$ increases also that reflects decreasing of equilibria temperature.

The fact that IW - end member of this trend is established both as megacrysts and consolidated rock xenoliths can be a basis for conclusion that more refractory megacrysts of ilmenite-pyrope lherzolite paragenesis also passed a stage of consolidation. In our opinion it excludes a possibility of $\mathrm{M}$ crystallization from kimberlite melt. Abundant traces of cataclasis in these megacrysts confirm this conclusion.

Our results permit to interpret established range as a product of deep-seated metasomatic processing of normal mantle peridotite (first of all sheared) by fluids enriched in $\mathrm{Ti}$, $\mathrm{Fe}, \mathrm{Ca}, \mathrm{K}$ and other non-coherent elements. Process took place in uplifting mantle diapir, that is reflected in Gar zone. Partial melting in the upper part of the diapir in combination with collecting re-crystallization led to forming of coarse-mega-crystalline rocks. Disintegration of these rocks (due to presence of residual melt) during kimberlite emplacement produce megacrysts.

Absence of crystallization trend in comparison to South Africa is due to general comparatively "cool" mantle conditions producing less scale of melting. In other words Dalnaya ilmenite assemblages were derived from several isolated chambers. At the same time our data approve general tendencies in evolution of titanium branch associations.

\section{References}

NIXON, P.H.\& BOYD, F.R. 1973. The discrete nodule association in kimberlites from northen Lesotho. In NIXON,P.H. (ed.) Lesotho kimberlites, Lesotho Nat. Dev. Corp., 67-75.

EGGLER, D.H. \& MacCALLUUM, M.E. 1976. A geotherm from megacrysts in the Sloan kimberlite pipes, Colorado. Carn. Inst. Wash. Yearbook 75, p. 538-541.

RODIONOV, A.S. 1988. Ilmenite peridotite xenoliths with zoned garnet from Dalnaya kimberlite pipe (Yakutia). In Ultramafic paragenesis minerals from kimberlites and conditions of their genesis, Novosibirski, 86-94 (in Russian).

RODIONOV, A.S.; AMSHINSKY, A.N.; POKHILENKO, N.P.; SOBOLEV, N.V. 1984. Xenoliths of ilmenitepyrope wehrlites and the problem of kimberlite megacrysts suite genesis. In $10^{\text {th }}$ Seminar "Geochemistry of magmatic rocks", (abst.), Moscow, GEOCHI, 153-154 (in Russian).

RODIONOV, A.S.; POKHILENKO, N.P.; AMSHINSKY, A.N. 1989. Megacryst suite in Yakutian kimberlites: new data. In Problems of kimberlite magmatism, Novosibirski, Nauka, Siberian Div., 120-126 (in Russian). 